\title{
Vertical variability of the properties of highly aged biomass burning aerosol transported over the southeast Atlantic during CLARIFY- 2017: Supplementary
}

Huihui Wu ${ }^{1}$, Jonathan W Taylor ${ }^{1}$, Kate Szpek ${ }^{2}$, Justin Langridge ${ }^{2}$, Paul I Williams ${ }^{1,3}$, Michael Flynn ${ }^{1}$, 5 James D Allan ${ }^{1,3}$,Steven J Abel ${ }^{2}$, Joseph Pitt ${ }^{1,5}$, Michael I Cotterell ${ }^{2,}$ 4, 6 , Cathryn Fox ${ }^{2}$, Nicholas W Davies $^{2,4}$, Jim Haywood ${ }^{2,4}$ and Hugh Coe ${ }^{1}$

${ }^{1}$ Department of Earth and Environmental Sciences, University of Manchester, Manchester, UK

${ }^{2}$ Met Office, Fitzroy Road, Exeter, EX1 3PB, UK

${ }^{3}$ National Centre for Atmospheric Science, University of Manchester, Manchester, UK

$10{ }^{4}$ College of Mathematics, Engineering and Physical Science, University of Exeter, UK.

${ }^{5}$ Now at: School of Marine and Atmospheric Science, Stony Brook University, Stony Brook, US

${ }^{6}$ Now at: School of Chemistry, University of Bristol, Bristol, UK, BS8 1TS

Correspondence to: Hugh Coe (hugh.coe@ manchester.ac.uk)

\section{S1 The calculation of enhancement ratios and MCE}

The enhancement ratios (ER) of $\mathrm{BC}$ and $\mathrm{OA}$ can be calculated by dividing them by the excess mixing ratio of $\mathrm{CO}$, after backgrounds have been removed (Lefer et al., 1994). The modified combustion efficiency (MCE) is defined as the excess mixing ratio of $\mathrm{CO}_{2}$ over the background to the sum of the excess mixing ratio of $\mathrm{CO}$ and $\mathrm{CO}_{2}: \mathrm{MCE}=\Delta \mathrm{CO}_{2} /(\Delta \mathrm{CO}+\Delta \mathrm{CO})_{2}$ (Yokelson et al., 2009). For an identified smoke, MCE can be calculated by determining the slope between $\mathrm{CO}$ and $\mathrm{CO}_{2}$

20 using an unconstrained linear orthogonal distance regression (ODR) and subsequently solving for $\mathrm{MCE}=1 /\left(1+\delta \mathrm{CO} / \delta \mathrm{CO}_{2}\right)$. $\mathrm{BC} / \triangle \mathrm{CO}$ can be also calculated by determining the slope between $\mathrm{BC}$ and $\mathrm{CO}$ using the unconstrained linear ODR, the same for $\mathrm{OA} / \Delta \mathrm{CO}$. However, when plumes are mixed into different air masses background values may change and this can significantly impact the MCE and ER calculation for BB smokes in transport region (Yokelson et al., 2013).

In the FT, this issue may not significantly affect the calculation as the background variations of species are likely to be small compared with the excess levels in plumes. The correlation between BC and CO is good (see Table S1) for most of flights. The slopes were determined by the unconstrained ODR fit and are defined as the $\mathrm{BC} / \Delta \mathrm{CO}\left(\mu \mathrm{g} \mathrm{m}^{-3} / \mathrm{ppmv}\right)$, similar calculation was used for $\mathrm{OA} / \Delta \mathrm{CO}\left(\mu \mathrm{g} \mathrm{m}^{-3} / \mathrm{ppmv}\right)$. For MCE, the slopes between $\mathrm{CO}$ and $\mathrm{CO}_{2}$ were also determined by the unconstrained ODR fit. The correlation between $\mathrm{CO}$ and $\mathrm{CO}_{2}$ in the FT is good for most of flights $\left(\mathrm{r}^{2}>0.8\right.$, see Table $\left.\mathrm{S} 1\right)$. C036, C037 and C047 are the flights with lower $\mathrm{r}^{2}(\sim 0.70)$.

In the $\mathrm{BL}$ where $\mathrm{BB}$ smoke plumes were diluted into a clean environment, the final concentrations were not much greater than the backgrounds, especially for $\mathrm{CO}_{2}$ which had a high background. It is not suitable for using ODR fit since there is not enough variation in the concentrations to obtain a reliable result. For example, the correlation $\left(r^{2}=0.28-0.88\right.$, 
Table S1) between $\mathrm{BC}$ and $\mathrm{CO}$ are low for most of flights, and there is not enough variation in $\mathrm{CO}_{2}$ to obtain a correlation between $\mathrm{CO}$ and $\mathrm{CO}_{2}$. As a result, we did not consider the MCE calculation, since the derived slopes $(\partial \mathrm{CO} / \partial \mathrm{CO} 2)$ are

35 misleading and $\mathrm{CO}$ and $\mathrm{CO}_{2}$ concentrations in plume were close to the $\mathrm{BL}$ background. In the $\mathrm{BL}$, the background of $\mathrm{BC}$ and OA is approximately zero. The lowest 5 th percentile for all the BL CO data was $65.8 \mathrm{ppbv}$ and the median of all the clean BL CO data was 66.5 ppbv, BL CO background is calculated to be 66 ppbv by averaging the two results. The background of $\mathrm{BL} C \mathrm{C}$ was then used to calculate the excess $\mathrm{CO}(\Delta \mathrm{CO}), \mathrm{BC} / \Delta \mathrm{CO}$ and $\mathrm{OA} / \Delta \mathrm{CO}$ ratios $\left(\mu \mathrm{g} \mathrm{m}^{-3} / \mathrm{ppmv}\right)$.

Table S1. Summary of the flight plume characteristics in the FT and BL separately: flight ID, flight data and $\mathbf{r}^{2}$ correlation between $\mathrm{CO}$ and $\mathrm{CO}_{2}, \mathrm{BC}$ and $\mathrm{CO}$ and $\mathrm{OA}$ and $\mathrm{CO}$.

\begin{tabular}{lcccccc}
\hline \multirow{2}{*}{ Flight } & \multirow{2}{*}{ Date } & $\mathrm{CO}$ vs $\mathrm{CO}_{2} \mathrm{r}^{2}$ & \multicolumn{2}{c}{$\mathrm{BC}$ vs CO r } & \multicolumn{2}{c}{${\mathrm{OA} \mathrm{vs} \mathrm{CO}{ }^{2}}^{2}$} \\
& & $\mathrm{FT}$ & $\mathrm{FT}$ & $\mathrm{BL}$ & $\mathrm{FT}$ & $\mathrm{BL}$ \\
\hline $\mathrm{C} 028$ & $16 / 08 / 2019$ & & & 0.76 & & 0.04 \\
$\mathrm{C} 029$ & $17 / 08 / 2019$ & & 0.68 & & 0.49 \\
$\mathrm{C} 030$ & $17 / 08 / 2019$ & & & 0.54 & & 0.48 \\
$\mathrm{C} 031$ & $18 / 08 / 2019$ & & & 0.85 & & 0.83 \\
$\mathrm{C} 032$ & $19 / 08 / 2019$ & & & 0.68 & & 0.70 \\
$\mathrm{C} 033$ & $22 / 08 / 2019$ & 0.85 & 0.89 & & 0.89 & \\
$\mathrm{C} 034$ & $23 / 08 / 2019$ & 0.89 & 0.94 & & 0.93 & \\
$\mathrm{C} 035$ & $23 / 08 / 2019$ & 0.94 & 0.95 & & 0.93 & \\
$\mathrm{C} 036$ & $24 / 08 / 2019$ & 0.72 & 0.88 & & 0.84 & \\
$\mathrm{C} 037$ & $24 / 08 / 2019$ & 0.71 & 0.85 & & 0.83 & \\
$\mathrm{C} 038$ & $25 / 08 / 2019$ & 0.86 & 0.94 & & 0.75 & \\
$\mathrm{C} 039$ & $25 / 08 / 2019$ & 0.85 & 0.94 & & 0.80 & \\
$\mathrm{C} 045$ & $29 / 08 / 2019$ & 0.87 & 0.93 & 0.27 & 0.90 & 0.01 \\
$\mathrm{C} 046$ & $30 / 08 / 2019$ & 0.85 & 0.98 & 0.74 & 0.93 & 0.38 \\
$\mathrm{C} 047$ & $01 / 09 / 2019$ & 0.70 & 0.89 & 0.49 & 0.83 & 0.68 \\
$\mathrm{C} 048$ & $01 / 09 / 2019$ & 0.98 & 0.98 & 0.53 & 0.99 & 0.38 \\
$\mathrm{C} 049$ & $02 / 09 / 2019$ & 0.97 & 0.99 & 0.71 & 0.98 & 0.63 \\
$\mathrm{C} 050$ & $04 / 09 / 2019$ & 0.98 & 0.99 & 0.61 & 0.90 & 0.64 \\
$\mathrm{C} 051$ & $05 / 09 / 2019$ & 0.94 & 0.96 & 0.88 & 0.93 & 0.88 \\
\hline
\end{tabular}

\section{$\mathrm{S} 2 \mathrm{~m} / \mathrm{z} 30$ to $\mathrm{m} / \mathrm{z} 46$ ratios from the AMS}

Nitrate is detected in the AMS using peaks at $\mathrm{m} / \mathrm{z}=30$ and 46 (Allan et al., 2003), representing the ions $\mathrm{NO}^{+}$and $\mathrm{NO}_{2}{ }^{+}$ 60 respectively. When sampling nitrate species, the ratio of these two peaks is determined by the heater temperature and the volatility of nitrate species (Drewnick et al., 2015). The AMS may detect nitrate species including salts such as $\mathrm{NH}_{4} \mathrm{NO}_{3}$, $\mathrm{NaNO}_{3}$ and $\mathrm{KNO}_{3}$, as well as organic nitrates. Higher $\mathrm{m} / \mathrm{z} 30$ to m/z 46 ratios were observed for less volatile nitrates, e.g.28 for $\mathrm{KNO}_{3}$ and 29.2 for $\mathrm{NaNO}_{3}$, compared to $\mathrm{NH}_{4} \mathrm{NO}_{3}$, since they decompose further before ionization (Alfarra et al., 2004; Drewnick et al., 2015). Rollins et al. (2010) measured m/z 30 to m/z 46 ratios of $0.99-5.30$ for various organo-nitrates. 
65 During CLARIFY, the $\mathrm{m} / \mathrm{z} 30$ to $\mathrm{m} / \mathrm{z} 46$ ratios ranged from 1 to 1.4 , from the AMS calibration using mono-disperse $\mathrm{NH}_{4} \mathrm{NO}_{3}$ particles. The ambient $\mathrm{m} / \mathrm{z} 30$ to $\mathrm{m} / \mathrm{z} 46$ ratios in the FT were slightly higher than the calibration values (Fig. S4). This indicated a small potential interference from organic species, but most of observed nitrates should be $\mathrm{NH}_{4} \mathrm{NO}_{3}$. Furthermore, the linear fitted C-ToF AMS NH$H_{4 \text { measured }}^{+} \mathrm{NH}_{4 \text { predicted }}^{+}$ratios of FT pollutants in period 2 and 3 were $(1.06 \pm$ $0.01)$ and $(1.05 \pm 0.02)$ respectively. The ammonium in the FT was sufficient to nearly fully neutralize the aerosol, which

70 further supports that the nitrate measured in the FT was mostly $\mathrm{NH}_{4} \mathrm{NO}_{3}$.

\section{References}

Alfarra, M. R.: Insights into atmospheric organic aerosols using an Aerosol Mass Spectrometer, University of Manchester, Institute of Science and Technology, Manchester, UK., 2004.

Allan, J. D., Jimenez, J. L., Williams, P. I., Alfarra, M. R., Bower, K. N., Jayne, J. T., Coe, H. and Worsnop, D. R.:

75 Quantitative sampling using an Aerodyne aerosol mass spectrometer 1. Techniques of data interpretation and error analysis, J. Geophys. Res., 108, doi:4090 10.1029/2002jd002358, 2003.

Drewnick, F., Diesch, J.-M., Faber, P., and Borrmann, S.: Aerosol mass spectrometry: particle-vaporizer interactions and their consequences for the measurements, Atmos. Meas. Tech., 8, 3811-3830, https://doi.org/10.5194/amt-8-3811-2015, 2015.

80 Lefer, B. L., Talbot, R. W., Harriss, R. C., Bradshaw, J. D., Sandholm, S. T., Olson, J. O., Sachse, G. W., Collins, J., Shipham, M. A., Blake, D. R., Klemm, K. I., Klemm, O., Gorzelska, K., and Barrick, J.: Enhancement of acidic gases in biomass burning impacted air masses over Canada, J. Geophys. Res., 99, 1721-1737, 1994.

Rollins, A. W., Fry, J. L., Hunter, J. F., Kroll, J. H., Worsnop, D. R., Singaram, S. W. and Cohen, R. C.: Elemental analysis of aerosol organic nitrates with electron ionization high-resolution mass spectrometry, Atmos. Meas. Tech., 3(1), 301-310, 85 doi:10.5194/amt-3-301-2010, 2010.

Yokelson, R. J., Crounse, J., DeCarlo, P., Karl, T., Urbanski, S., Atlas, E., Campos, T., Shinozuka, Y., Kasputin, V., Clarke, A., Weinheimer, A. J., Knapp, D., Montzka, D. D., Holloway, J., Weibring, P., Flocke, F., Zheng, W., Toohey, D., Wennberg, P. O., Wiedinmyer, C., Mauldin, L., Fried, A., Richter, D., Walega, J., Jimenez, J. L., Adachi, K., Buseck, P. R., Hall, S. R., and Shetter, R.: Emissions from biomass burning in the Yucatan, Atmospheric Chemistry and Physics, 9, 5785, $90 \quad 2009$.

Yokelson, R. J., Andreae, M. O., and Akagi, S. K.: Pitfalls with the use of enhancement ratios or normalized excess mixing ratios measured in plumes to characterize pollution sources and aging, Atmos. Meas. Tech., 6, 2155-2158, https://doi.org/10.5194/amt-6-2155-2013, 2013. 


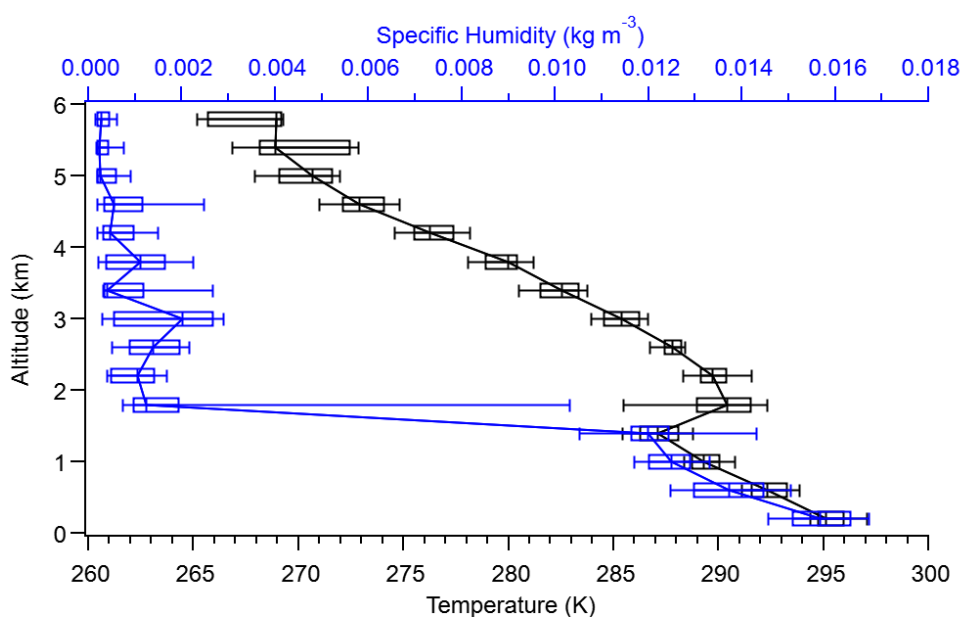

Figure S1: The vertical distribution of temperature (black) and specific humidity (blue) during the campaign. The boxes and whiskers represent $10 \%, 25 \%$, median, $75 \%$ and $90 \%$ in every $400 \mathrm{~m}$ bin.
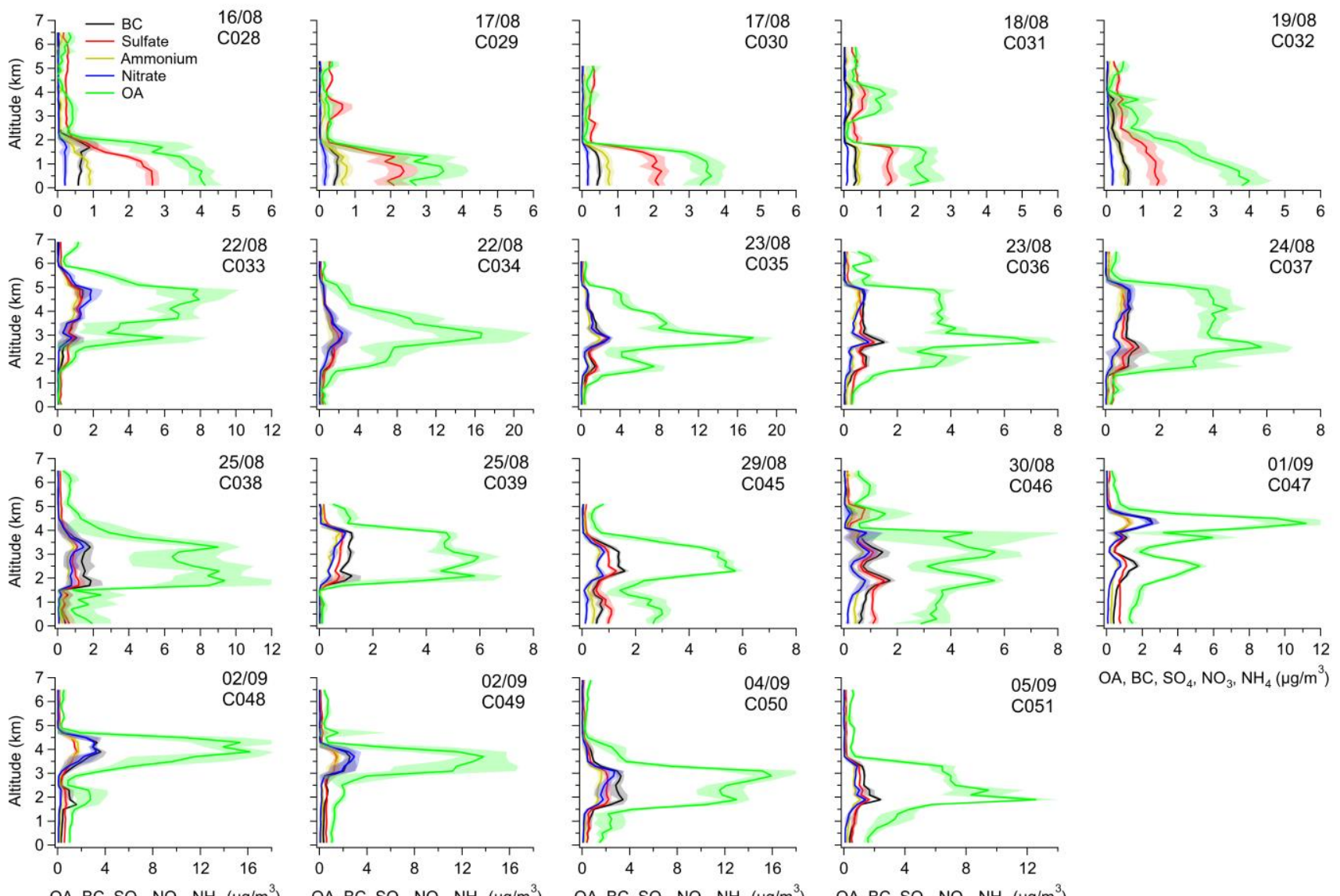

$\mathrm{OA}, \mathrm{BC}, \mathrm{SO}_{4}, \mathrm{NO}_{3}, \mathrm{NH}_{4}\left(\mu \mathrm{g} / \mathrm{m}^{3}\right)$

$\mathrm{OA}, \mathrm{BC}, \mathrm{SO}_{4}, \mathrm{NO}_{3}, \mathrm{NH}_{4}\left(\mu \mathrm{g} / \mathrm{m}^{3}\right)$

$\mathrm{OA}, \mathrm{BC}, \mathrm{SO}_{4}, \mathrm{NO}_{3}, \mathrm{NH}_{4}\left(\mu \mathrm{g} / \mathrm{m}^{3}\right)$

$\mathrm{OA}, \mathrm{BC}, \mathrm{SO}_{4}, \mathrm{NO}_{3}, \mathrm{NH}_{4}\left(\mathrm{\mu g} / \mathrm{m}^{3}\right)$

100 Figure S2: The average vertical distribution of different chemical composition concentrations for each flight. The lines and shades represent the average and standard deviation. 

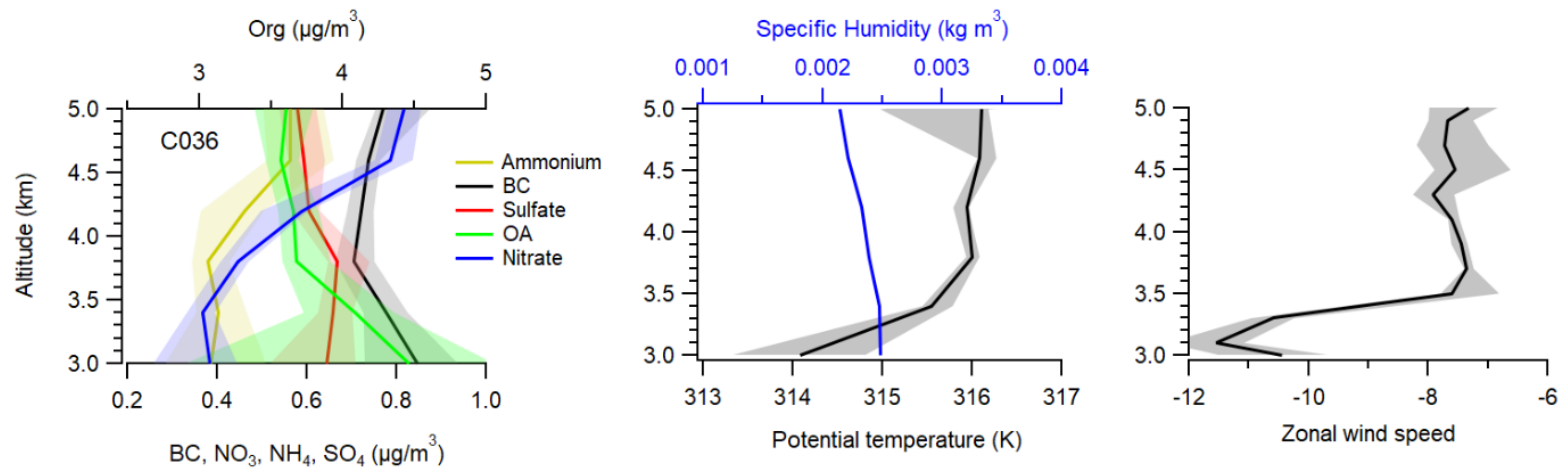

105 Figure S3: The vertical distribution $(\mathbf{3 0 0 0}-\mathbf{5 0 0 0} \mathbf{~ m})$ of different chemical composition concentrations in flight C036, and the vertical distribution of potential temperature and specific humidity and zonal wind speed. The lines and shades represent the $25 \%$, median and $75 \%$ in every $400 \mathrm{~m}$ bin.
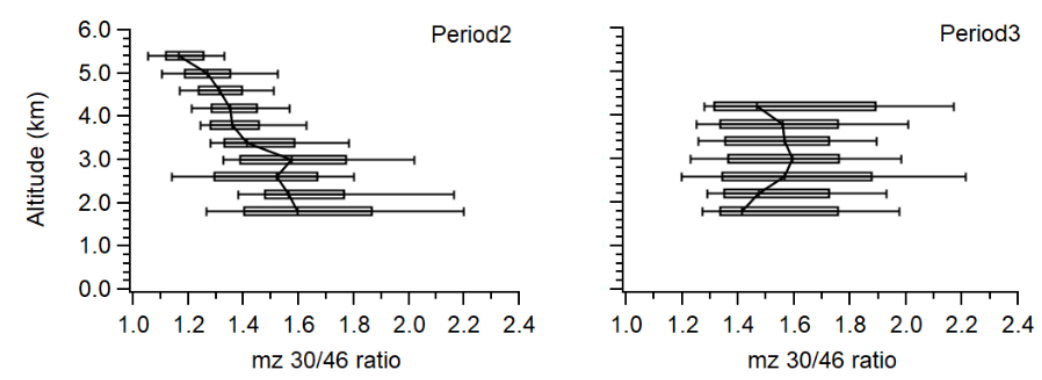

110 Figure S4: The vertical distribution of $\mathrm{m} / \mathrm{z} 30$ / 40 ratios in the BB-polluted FT. The boxes and whiskers represent $10 \%, 25 \%$, median, $75 \%$ and $90 \%$ in every $400 \mathrm{~m}$ bin. 